\title{
Effect of Remuneration on Productivity of Academic Staff of Selected Tertiary Institutions in Bauchi State, Nigeria
}

\author{
Mohammed Rasheed Aliyu
}

Master of Arts in Human Resource Management, Associate Member of the Nigerian Institute of Management (AMNIM), School of Management Studies, Abubakar Tatari Ali Polytechnic Bauchi, Nigeria

\section{Hashim Sabo Bello}

$\mathrm{PhD}$, Full Member of the Nigerian Institute of Management, School of Management Studies, Abubakar Tatari Ali Polytechnic Bauchi, Nigeria

\section{Mansur Bello}

Master of Arts in Human Resource Management, Faculty of Management \& Social Sciences, Department of Business Management, Taraba State University Jalingo, Nigeria

\begin{abstract}
The study was on remuneration and productivity of academic staff of selected tertiary institutions in Bauchi state, Nigeria. It investigates the effect of remuneration such as pay system, benefits and incentives on the productivity of academic staff of selected tertiary institutions. The study was to determine the effect of remuneration on the productivity of academic staff of selected tertiary institutions in Bauchi state Nigeria. The study was based on Herzberg's two-factor theory. The study adopts descriptive survey designs. The study population was 1389 and the sample of the study was 311 respondents, selected using a systematic random sampling technique. Survey method of data collection was used. The closed-ended questionnaire was used as an instrument for data collection. Data were analyzed using simple linear regression analysis. The findings of the study revealed that there is a significant positive effect of remuneration on the productivity of academic staff where $(\mathrm{R}$-value $=.645$, Adjusted $\mathrm{R}=.415, \mathrm{p}<.001)$. The study concludes that remuneration has the effect on the productivity of academic staff of selected tertiary institutions in Bauchi state, Nigeria. The study recommends that the institutions should ensure fair, equitable, just and transparent remuneration to all academic staff based on their value. The study improves researchers' effort in understanding the study variable and has opened up a debate on the effect of remuneration on the productivity of academic staff. The study suggests that further study should be carried out to cover the North-Eastern geographic region of the country, to give a wider coverage where the result can be used for generalization purposes.
\end{abstract}

Keywords: productivity, academic staff, remuneration, pay system, benefits, incentives.

JEL Classification: D24, M5, M52, E42.

(C) The Authors, 2018. This article is published with open access at Sumy State University.

\section{Introduction}

Productivity in developing nations that include African countries appear to be extremely low, GDP per capita and average firm-level sales per employee in manufacturing-commonly known as labor revenue productivity across a sample countries and the message seems clear that developing countries firms have lower levels of labor productivity (Nicholas, Aprajit, David \& John, 2010). African nations were characterized by poor productivity, even though there is volatility in input and output variables especially total factor productivity and labor productivity. Qualities of human capital were not only low but deteriorate in Nigeria, due to low public expenditure on education and the brain drain phenomenon (Adeola, 2005). Despite enhanced employee productivity institutions establishment, poor budgetary support hampered their operations (Adeola, 2005). A decline in labor productivity had affected economic growth. Komal, (2007), stated that human development strategy implementation is the challenge towards enhancing organizational and employee productivity. This means that productivity is the problem that affects many organizations in Nigeria of which selected tertiary institutions in Bauchi state were not an exception.

\section{Problem Statement}

Employee productivity is one of the most important parts of achieving organizational objectives. The happier and less stressful employees are the more effective and efficient they can perform. Komal (2007) stated that human development strategy implementation is the challenge towards enhancing organizational and employee 
productivity. Productivity is one of the problems that affects many organizations in Nigeria of which selected tertiary institutions in Bauchi state were not an exception. Akinyele (2009), citing Lambert (2005), stated that provision of adequate fringe benefits, supervision, work method, work environment etc. are key factors to higher productivity.

The tertiary education system has been criticized for being inefficient and ineffective, making it irrelevant to the needs of a global edge. The major issues in Nigerian higher education and Bauchi state are similar to those in most developing countries around the world. Problems such as access, infrastructure, quality, funding, welfare, efficient and effective management, and governance have been some of the major issues (Teboha, 2000).

Despite intervention to institutions on or like essential physical infrastructure for teaching and learning; instructional material and equipment; research and publication; academic Staff Training and Development (Baffa, 2017). The implementation of the new consolidated tertiary institutions salary structure (CONTISS) in 2007 and implementation of the consolidated polytechnic, colleges of education academic staff salary structure (CONPCASS) in 2013 (NSIWC, 2007 \& 2013). There is no much improvement in the efficiency and effectiveness of the institutions and academic staffs, because of the incessant strikes due to job dissatisfaction. This has resulted to poor academic standard and performance in tertiary institutions and many parents' yearin-year out send their children to other countries abroad where they believe the academic standard of the institutions over there is sound and high compared to ours (Kawugana, 2016). This study investigates remuneration as a possible factor that influences the productivity of academic staffs of selected tertiary institutions in Bauchi State, Nigeria; hence the need for this study.

\section{The Purpose of the Study}

The purpose of this study is to determine the effect of remuneration on the productivity of academic staff of selected tertiary institutions in Bauchi State, Nigeria.

\section{Objectives of the Study}

$>$ To determine the level of remuneration of the academic staff of selected tertiary institutions in Bauchi state, Nigeria.

$>$ To determine the level of productivity of the academic staff of selected tertiary institutions in Bauchi state, Nigeria.

To determine the effect of remuneration on the productivity of academic staff of selected tertiary institutions in Bauchi state, Nigeria.

\section{Research Questions}

What is the level of remuneration of the academic staff of selected tertiary institutions in Bauchi, Bauchi state, Nigeria?

$>$ What is the level of productivity of the academic staff of selected tertiary institutions in Bauchi, Bauchi state, Nigeria?

$>$ What is the effect of remuneration on the productivity of academic staff of selected tertiary institutions in Bauchi, Bauchi state, Nigeria?

\section{Research Hypotheses}

$\mathrm{H}_{1}$ : There is a significant effect of remuneration on the productivity of academic staff of selected tertiary institutions in Bauchi state, Nigeria.

$\mathrm{H}_{0}$ : There is no significant effect of remuneration on the productivity of academic staff of selected tertiary institutions in Bauchi state, Nigeria.

\section{The Scope of the Study}

This includes geographical, content and theoretical scope of the study.

Geographical Scope: This study was conducted from Abubakar Tatari Ali Polytechnic, Bauchi, Federal Polytechnic Bauchi and College of Education, Azare, Bauchi state, Nigeria. The study was conducted because of the large size of respondents whose responses can be generalized.

Content Scope: The study covers the pay system, benefits and incentives on the independent variable while individual capacity and task capacity on the dependent variable.

Theoretical Scope: Fredrick Herzberg's, two-factor theory (known as motivators-hygiene theory) of 1959 cited in Nwachukwu (2007), was chosen as the most suitable for this study, due to its relevance to a work 
situation. The theory explains that there are certain satisfiers and dissatisfies for an employee at work. Dissatisfies (hygiene factors) include working condition, salary, job security, company policy, interpersonal working relationships. Motivators (satisfiers) include recognition, promotion, achievement, responsibility and personal advancement. Herzberg pointed out that the 'motivators' were all intimately related to the content of the work. He maintained that the absence of motivators does not lead to job dissatisfaction, but merely to lack of job satisfaction (Invacenvich, et al., 2005).

\section{The Significance of the Study}

The study was significant even though studies were conducted universally on this study area but they are basically on manufacturing, banking, telecommunications, health sectors etc. with very few on university and primary education. This study covers some selected tertiary education institutions in Bauchi state, which were not covered by other studies, using base pay, benefits and incentives as variables to determine whether remuneration has a significant effect on the productivity of academic staffs.

\section{Conceptual Framework}

\section{Independent Variable \\ $\underline{\text { Remuneration }}$}

Pay system

Employee benefits

Employee incentives

Source: Adapted from Ngirwa (2005) in Elisifa (2014) and Ruch \& Hershauer, 1974

\section{Dependent Variable \\ Productivity}

Task Capacity

Individual Capacity

\section{Related Literature Review}

REMUNERATION this is the rewarding of employee fairly, equitably, and consistently based on their value and contribution to the organization. Australian Government, Executive Remuneration Information Paper, (2010) stated that remuneration is defined in the Corporations Act by reference to the accounting standards "AASB 124" defines 'remuneration' to mean 'compensation', which includes:

Short-term employee benefits such as wages, salaries and social security contributions, paid annual leave and paid sick leave, profit-sharing and bonuses (if payable within twelve months of the end of the period) and non-monetary benefits (such as medical care, housing, cars and free or subsidized goods or services) for current employees;

$>$ Post-employment benefits such as pensions, other retirement benefits, post-employment life insurance and post-employment medical care;

$>$ Other long-term employee benefits including long-service leave or sabbatical leave, jubilee or other longservice benefits, long-term disability benefits and, if they are not payable wholly within twelve months after the end of the period, profit-sharing bonuses and deferred compensation;

\section{Termination benefits and}

Share-based payment.

According to Joshi \& Venkatesh, (2006) remuneration centers on factors such as job complexity, the company's ability to pay, and executive human capital. Compensation measures the total remuneration, in cash or in kind, that accrues to employees in return for their work during the accounting period, regardless of when they are paid. Compensation is consistent with the treatment recommended by the System of National Accounts 2008 (SNA), in which compensation reflects total remuneration and is measured on an accrual basis.

Pay system: Bohan (2004) explains that traditional pay systems were based on the three factors: (i) the job, (ii) maintaining the level of equality in standard pay among employees in the organization, and (iii) paying competitive salaries. In the traditional pay systems, employees were not encouraged to acquire new skills and were not rewarded if they did. The increase of an employee's pay depended on change on the cost of living and employees regarding the increase in pay as the entitlement without accounting for their own performance, or that of the organization. Pay has a paramount importance in satisfying their economic need. The pay is so significant because when workers are satisfied with pay, their behavior and attitude could be influenced towards the desired objective (Onukwube, 2012).

Employee Benefits: employee benefits are all forms of consideration given by an entity in exchange for service rendered by employees or for the termination of employment (IFRS, 2012). 
Employee Incentives: Fringe benefits, which are supplementary in nature, not worked for, and are usually given to all employees of an organization, irrespective of their different performances such as annual leave allowances, salary advance and educational assistance (Adeniji and Osibanjo, 2012). Abdul, et al (2014) stated that incentives are indirect compensation offered by organizational which include; social security, retirement benefits, holidays, vacation etc.

PRODUCTIVITY is defined as an average measure of the efficiency of production. Employee productivity is defined as an assessment of the efficiency of a worker or group of workers. This can be assessed relative to an average of the employee doing similar work (Rob, 2015). Zelensk \& Murphy (2008) citing Campbell et al. (1993) stated that individual productivity is the degree to which an employee executes his or her role with reference to certain specified standards set by the organization. Rolloos (1997) defined productivity as, that which people can produce with the least effort. Dorgan (1994) defines productivity as, the increased functional and organizational performance, including quality. These definitions suggest that productivity is the measure of economic performance, as well as resources used to produce goods and services (Bernardin \& Russell, 1998, Ross, 1981). Firms that derive their productivity advantage from firm-specific knowledge may wish to provide better working conditions with the hope that this would reduce worker turnover and minimize the risk of their productivity advantage spilling over to competing firms (Glass \& Saggi, 2002). Operationally, employee productivity is referred to the value, effort and commitment put to achieve a set goal. Employee productivity can be achieved when there is an adequate number of hours worked, task capacity, individual capacity and individual effort.

Task capacity refers to the technological capability of the organization, how the organization designs the task and the physical inputs provided by the organization. Task capacity refers to organization available technology and technological change by employing the implementing principles, a reversal of the logic employed by (Slocum and Sims, 1980 cited in Song, 2008).

Individual capacity refers to the knowledge, skills and abilities possessed by an individual employee in an organization, which will make him perform their duty effectively or not. The way to incorporate new (individual) ideas into the organizational knowledge (or intellectual capital) must be free of any barriers (Mueller, 2008). Wenger (2000) knowledge is seen as being co-constructed through interaction among members of a community engaged in a joint enterprise. Skills also constitute the product of education, training and job experience together with relevant technical know-how (Bjørnåvold and Tissot, 2000).

\section{Remuneration and Productivity}

Emmanuel (2013) studied the relationship between compensation and employee productivity in the banking industry in Ghana. It was found that the test result is significant, and therefore, there is a statistically significant relationship between compensation and productivity in an organization. This has clearly shown that compensation has a direct influence on employee productivity. It was concluded that the organization can achieve this, if there is transparency in the reward system and if the rewards or compensation meets the aspirations of the beneficiaries.

Sandilyan, Mousimi, Amitabh \& Monojit (2012) conducted a study on the effect of remuneration and rewards on employee motivation in selected hotels in West Bengal, India. The findings show that reward and remuneration policies have an impact on a senior and middle-level employee, and therefore, improve their productivity.

Halkos \& Bousinakis (2010) found that employees who obtained satisfying wages and felt safe could directly enhance productivity, and their experiences, knowledge and skills would benefit the organization, hence there is a clear linkage between stress and job satisfaction.

Roberto, Davide and Paolo (2014) conducted a study on the flexible pay system and labor productivity in Emilia-Romagna manufacturing firm. The finding shows that flexible payment systems are not just a mere mechanism for inducing greater workers' effort, but the tool by which the labor productivity effect of organizational changes materializes. Conclusively it shows that non-price incentives are as important as price incentives for achieving higher productivity targets.

Karim and Roger (2005) studied job satisfaction of University academics: concerning the perspective of Uganda the findings revealed that not unexpectedly, and consistent with the research literature, Ugandan academics were disenchanted with remuneration. 
Nadia (2006) conducted a study on incentive performance related pay and productivity on a company in Ukraine. The finding revealed that monetary incentive performance-related remuneration schemes are positively associated with labor productivity. Besides these variables property form, capital and some regulation factors also influence productivity.

Mensah (2012) studied the impact of indirect compensation on employee productivity in the central university college, Ghana. The study shows that indirect compensation plays a significant role in motivating employees. The study concluded that though management of CUC implements some of the indirect compensation packages, and other benefits that are not satisfactorily administered has an unenthusiastic effect of reducing the morale of employees; thus, their productivity level is negatively affected. This shows that there is the relationship between compensation and productivity of employees.

\section{Gaps Identified in the Literature}

Several studies on remuneration and productivity have been done globally, in Asia e.g. Sandilyan, Mousimi, Amitabh \& Monojit (2012), Europe e.g. Nadia (2006), Africa e.g. Mensah (2012), Karim \& Roger (2005), Emmanuel (2013) etc. None of the above studies have been done in North East Nigeria. This study therefore was intended to close this gap.

Furthermore, the above studies were done to cover various sectors of the economy. The current study was done to cover tertiary institutions in Bauchi state where academic staffs provide new information in regard to remuneration and productivity.

\section{Methodology}

The study adopts descriptive survey designs.

\section{Target Population}

The population of the study was all academic staff of selected tertiary institutions in Bauchi state, Nigeria. The population was 1389 members of academic staff of selected tertiary institutions in Bauchi state. They include Abubakar Tatari Ali Polytechnic 255, Federal Polytechnic 413 and College of Education 721. The academic staff of selected tertiary institutions constitutes the population of the study because they are the people who have the knowledge or information the study wants.

\section{Sample Size}

The sample was arrived using Slovene's formula for sample size determination. The adjusted sample size was arrived using James, Joe and Chardwick formula for adjusted sample size determination (James, Joe, and Chadwick, 2001). Table 1 shows the population distribution, minimum sample size and sample size adjusted for response rate.

Table 1. Population distribution, minimum sample size and sample size adjusted for the response rate

\begin{tabular}{|l|c|c|c|}
\hline \multicolumn{1}{|c|}{ Category } & Population size & $\begin{array}{c}\text { Minimum sample } \\
\text { size }\end{array}$ & $\begin{array}{c}\text { Sample size adjusted for } \\
\text { response rate }\end{array}$ \\
\hline Abubakar Tatari Ali Polytechnic, Bauchi & 255 & 57 & 71 \\
\hline Federal Polytechnic, Bauchi & 413 & 93 & 116 \\
\hline College of Education, Azare & 721 & 161 & 202 \\
\hline Total & $\mathbf{1 3 8 9}$ & $\mathbf{3 1 1}$ & $\mathbf{3 8 9}$ \\
\hline
\end{tabular}

Source: field survey, 2017

\section{Sampling Strategy}

Systematic random sampling technique was used to select respondents for the study.

\section{Data Collection Method}

Survey method of primary data collection was used, closed-ended standardize questionnaire adapted from Scott (2013) and Steve (2017), is the instrument for data collection using the Likert five-point scale of strongly disagree, disagree, undecided, agree and strongly agree. The instrument is divided into three sections: Section A contains respondent's characteristics; Section B contains questions on remuneration, which include base pay, benefits and incentives; Section $\mathbf{C}$ contains ten questions on the productivity of academic staffs.

\section{Validity and Reliability}

Face validity of the instrument was performed by an expert from the college of economics and management. Content validity index was used to test the validity of the instrument. However, five experts in that field were 
used to judge the content domains of a scale through the use of rating scales. The outcome shows that the instrument is valid because $\mathrm{CVI}=.80$. Construct validity was done using Kaiser-Meyer-Olkin (KMO) measure of sampling adequacy and the result was stated that the KMO values were above 0.783 , the constructs were accepted because the acceptable rule shows that the construct was good. For reliability:

Test-retest method was used to measure the reliability of the instrument, the instruments were administered twice with a two weeks' interval on twenty persons and the obtained results were compared and found that they did not differ a lot in the first and the second survey respectively; implying that there was a consistency, hence reliability. Internal Consistency method of reliability was used through the approach of Cronbach's Alpha using SPSS. The results were .872 this shows that the internal consistency is good.

\section{Data Analysis}

Data from the field were compiled, sorted, edited and coded to have the required quality, accuracy and completeness. The data were entered into the computer using the Statistical Package for Social Sciences (SPSS V. 21.0) for analysis. The study used frequencies and percentages distributions and cumulative percent to analyze data on profile characteristic of the respondents, using tables, because the data was ordinal. Arithmetic mean and standard deviation was used in analyzing respondent responses in section $\mathbf{B}$ and $\mathbf{C}$ of the instrument to determine the level of job satisfaction and productivity of academic staff. Table 2 shows the interpretation guide for data analysis.

Table 2. Interpretation guide for data analysis

\begin{tabular}{|l|l|l|l|}
\hline$\#$ & \multicolumn{1}{|c|}{ Mean Range } & \multicolumn{1}{|c|}{ Response Mode } & \multicolumn{1}{c|}{ Interpretation } \\
\hline 5 & $4.20-4.99$ & Strongly Agree & Very Satisfactory \\
4 & $3.40-4.19$ & Agree & Satisfactory \\
3 & $2.60-3.39$ & Undecided & Fairly Satisfactory \\
2 & $1.80-2.59$ & Disagree & Unsatisfactory \\
1 & $1.00-1.79$ & Strongly Disagree & Very Unsatisfactory \\
\hline
\end{tabular}

Source: field survey, 2017

Linear Regression Analysis was used in determining if there is a significant effect of remuneration on the productivity of academic staff, at $5 \%$ level of significance $(\alpha=0.005)$ which respondents and variables used.

\section{Presentation and Analysis}

\section{Responses Rate}

The researcher distributed 389 questionnaires but was able to retrieve only 315 questionnaires that were correctly filled and answered. This gave a retrieval rate of $81 \%$, according to Amin (2005), if the response rate is more than $70 \%$, this is enough to carry on and continue with data analysis.

Respondents' responses on the remuneration of the academic staff of selected tertiary institutions in Bauchi state, Nigeria.

Table 3. The summary of IV and DV mean and Std. Deviation

\begin{tabular}{|l|c|c|c|}
\hline \multicolumn{1}{|c|}{ Variables } & Average Mean & Std. Deviation & Interpretation \\
\hline Remuneration & 3.4166 & 1.20614 & Satisfactory \\
\hline Productivity & 3.3895 & 1.16372 & Fairly satisfactory \\
\hline
\end{tabular}

Source: primary data, 2017

The Table 3 generally revealed that remuneration of the academic staff of selected tertiary institutions in Bauchi state, Nigeria, was assessed by the respondents as satisfactory. Because the average mean for the variable was 3.41657 and standard deviation of 1.20614. This implies that respondents were satisfied with the institutions' pay system, just that they are dissatisfied with the mode of benefit payment. This implies that academic staff was satisfied with the equitable, just and fair pay system. They were also satisfied with the amount of recognition and career advancement but fairly satisfied with commendations received at work.

The findings revealed that respondents (academic staff of selected tertiary institutions in Bauchi state, Nigeria) have satisfactorily remuneration package. This signifies that academic staffs maintaining and retaining was based on the remuneration package of the institutions. The institutions should look into the unsatisfactory areas and proper solution to such issues. This has agreed with the hygiene and motivator factors of Herzberg theory that salary, recognition, achievement etc. were very vital to the success of the organization. That if properly taken care it will lead to job satisfaction and increase in productivity. 
Further Table 3, revealed that the productivity of academic staff in selected tertiary institutions in Bauchi state, Nigeria was assessed by the respondents as averagely fairly satisfactory. This was attributed to the fact that the respondent's average mean was 3.3895, and the standard deviation was 1.16372 .

Based on the findings it implies that academic staffs of selected tertiary institutions in Bauchi state, Nigeria were unsure that task capacity and individual capacity increase productivity.

Table 4 shows regression analysis for the effect of remuneration on the productivity of academic staff of selected tertiary institutions in Bauchi state, Nigeria.

Table 4. Regression analysis for the effect of remuneration on the productivity of academic staff of selected tertiary institutions in Bauchi state, Nigeria

\begin{tabular}{|c|c|c|c|c|c|c|c|}
\hline & Model & $\mathbf{R}$ & R Square & & Square & Std. Err & Estimate \\
\hline & 1 & $.645^{\mathrm{a}}$ & .416 & & & & \\
\hline & Model & Sum & quares & $\mathrm{df}$ & Mean Square & $\mathrm{F}$ & Sig. \\
\hline & Regression & & .834 & 1 & 30632.834 & 223.308 & $.000^{\mathrm{b}}$ \\
\hline & Residual & & .544 & 313 & 137.177 & & \\
\hline & Total & & .378 & 314 & & & \\
\hline & Model & & ndardized C & & $\begin{array}{l}\text { Standardized } \\
\text { Coefficients }\end{array}$ & $\mathrm{t}$ & Sig. \\
\hline & & $\mathrm{B}$ & & & Beta & & \\
\hline & (Constant) & 25.746 & & & & 7.945 & .000 \\
\hline 1 & Remuneration & 1.643 & & & .645 & 14.943 & .000 \\
\hline
\end{tabular}

a. Dependent Variable: Productivity of academic staffs

The results presented in Table 4, revealed that remuneration can significantly explain the variance in productivity of academic staff by $.416 \%$ (Adjusted $\mathrm{R}=0.415, \mathrm{p}<0.01$ ). This shows that the productivity of academic staff changes significantly with respect to remuneration. Therefore, $\mathrm{H}_{0}$ was rejected and conclude that there is a significant effect of remuneration on the productivity of academic staff in selected tertiary institutions in Bauchi state, Nigeria because of $r=64.5 \%$. The Table explains the coefficient of the regression equation as, $\mathrm{y}=25.746+1.643 \mathrm{x}$.

\section{Discussion of Findings}

The objective of this study was to determine the effect of remuneration on the productivity of academic staffs of selected tertiary institutions in Bauchi state, Nigeria. The study found a moderately significant effect of remuneration on the productivity of academic staffs. The result implies that remuneration such as pay system, benefits and incentives have the impact on the productivity of academic staffs. This study was supported by Nadia (2006) who says that monetary incentive related remuneration schemes are positively associated with labor productivity. The study agrees with Sandilyan et al. (2012) who says remuneration policies have the impact on senior and middle-level employee and therefore improve their productivity. This was equally supported by Holkos \& Bousinakis (2010) who says that satisfying wages could directly enhance the productivity of employees and their skills and knowledge would benefit the organization.

The descriptive analysis also reveals that the independent variables have a positive impact on the productivity of academic staffs. The study was fairly satisfactory that remuneration has the impact of productivity. The study agrees with Emmanuel (2013) who stated that compensation has a direct influence on employee productivity and concluded that it is achieved through transparency in the reward system. As supported by Mensah, (2012) who says if the remuneration packages are not satisfactorily administered have an effect on reducing the morale of employee thus their productivity.

The study disagrees with the findings of Karim \& Roger (2005) which stated that not unexpectedly, and consistent with the research literature, Ugandan academics were disenchanted with remuneration.

\section{Conclusion}

To sum up all, therefore, it is worthy of note that remuneration has to do with a method of promoting morale, increasing motivation and foster organizational cohesion. Remuneration awarded to organizations increases productivity levels because the organization is looking out for the collective good of the whole organization. Remuneration can motivate employees to be more productive but does not have to necessarily be compensation based. Remuneration can also be praise or recognition. However, compensated remuneration can be effective 
in long-term motivation and productivity, such as a raise or promotion. Remuneration increases overall employee morale provided the benefits are regarded as equitable. In other words, giving tiered or incremental bonuses based on which employee is the most productive, the second most productive and so on. Overall morale improves if each employee is granted a chance to reach a set of goals instead of setting one high goal that only one employee can achieve. In connection with the aforesaid as this study was meant to determine the effect of remuneration on the productivity of academic staff of selected tertiary institutions in Bauchi state, Nigeria. Therefore, the study found a significant effect of remuneration on the productivity of academic staff. From the above finding, one can deduce that productivity is the glue, which holds employee and employer together. This indicates that remuneration which is not exploitative enhance employee performance. A careful and efficient management of remuneration packages to some extent determine the progress of an organization. This does not mean that factors such as making an employee to have a sense of belonging in an organization do not enhance performance, but an employee who gets equivalent of what he put in an organization stands to perform higher.

\section{Recommendations}

It was recommended that tertiary institutions in Bauchi state should build sustainable remuneration policy that is transparent, fair, equitable and consistent base on the value of employee contribution. Bias, favoritism, discrimination in relation to promotion, commendation, training, incentives and other benefits should be avoided.

\section{Contribution to Knowledge}

The study improves researchers' effort in understanding the effect of remuneration on the productivity of academic staffs of selected tertiary institutions in Bauchi state Nigeria. Statistically, regression analysis results indicated that remuneration variables have the impact on the productivity of academic staff. Academically, the study has generated information that establishes the effect of remuneration on the productivity of academic staff.

\section{Area for Further Studies}

There is a need for further study to cover the North Eastern states tertiary institutions to have a wider geographical coverage and a larger population where the result can be used for generalization purposes. Also, comparative study should be done between federal and state-owned tertiary institutions in the state to determine the influence of remuneration on the productivity of academic staff.

\section{References}

1. Abdul, H., Muhammad, R., Hafiz, M., Kashif, Z., Ghazanfar, Ali, \& Muhammad, A. (2014). Impact of Compensation on Employee Performance (Empirical Evidence from Banking Sector of Pakistan), International Journal of Business and Social Science, 5(2), 302-309.

2. Abubakar Tatari Ali Polytchnic, Bauchi (2016). Academic Staffs Population. Establishment Department.

3. Abiodun, O. \& Adekola, G. (2015). Trends and Transformation of Higher Education in Nigeria: Management, Leadership, Governance and Quality. University of Portharcourt, Reviers state, Nigeria.

4. Adeniji, A. A., Osibanjo, A. O. (2012). Human resource management: Theory and practice, Pumark.

5. Adeola, F. A. (2005). Productivity and Performance in Developing Countries: Overview on Productivity Based on UNIDO Supplied Data for the period of 1962-2000. Case Study of Nigeria.

6. Akinyele, S. T. (2009). A Critical Assessment of Environmental Impact on Workers' Productivity. Nigeria. Business Journal, 1(1), 50-61.

7. Ali, S. A. Y., Ali, A. A., \& Abdiquni, A. A. (2013). Working Conditions and Employee Productivity in Manufacturing Companies in Sub Saharan Africa. Education Research International (SAVAP International), 2(2), 67-78.

8. Amin, M. E. (2005). Social Science Research: Conception, Methodology and Analysis. Makerere University Press.

9. Australian Government (2000). Corporations \& Market Advisory Committee, Executive Remuneration. Information Paper. ISBN 978-0-9806747-4-3. www.camac.gov.au.

10. Baffa, A. B. (2017). Meeting with Head of Beneficiary Institutions. Executive Secretary TETFund. Press Brief.

11.Bernardin, J. \& Russel, E. A. (1998). Human Resource Management: An Experimental Approach, McGraw Hill Irwin Corporation New York.

12.Bjornavold, J. \& Tissol, P. (2000). Glossary on Identification, Assessment and Validation of Qualifications and Competences, Transparence and Transferibility of Qualifications. Documents De Trabajo CEDEFOP. 
13.Bohan, F. (2004). Hidden Power of Productivity: Improving Productivity by $30 \%$ Without Layoffs! USA: AuthorHouse.

14.College of Education, Azare. (2016). Academic Staffs Population. Establishment Department.

15.Cameron, J. and Pierce, W. D. (1994). Reinforcement, reward and intrinsic motivation: a meta-analysis. Review of Educational Research, 64, 363-423.

16.Community Development Library (1997). Productivity and Quality Management: A Modular Program, Concepts, Processes \& Techniques. APO-ILO. pp. 828.

17.Cronbach, L. J. (1951). Coefficient Alpha and the Internal Structure of Test, Psychometrika, 16,(3), 297-334.

18.Dorgan, C.E. (1994). Productivity Link to the Indoor Environment Estimated Relative to ASHRAE 621989 Proceedings of Health Buildings '94, Budapest, pp. 461-472.

19.EICC VAP Audit Operations Manual v5.0.1, Strictly Internal to EICC Recognize Audits Only. Retrieved on 29-05-2017@10:00am.

20.Elisifa, N. (2014). Determinants of Job Satisfaction among Members of Academic Staff. Moshi University College of Cooperative and Business Studies, Moshi Tanzania. Retrieved December 14, 2016.

21.Emmanuel, E. Yamoah (2013). Relationship between Compensation and Employee Productivity. Singaporean Journal of Business Economic, 2(1). 110-114.

22.Federal Polytechnic, Bauchi. (2016). Academic Staffs Population. Establishment Departemtent.

23.Federal Republic of Nigeria (2004). National policy on education. Lagos: National Education Research and Development Council(NERDC) Press.

24.Garrison, M. \& Bly, M. E. (1997). Human Relations; Productive Approaches for the Work Place. Massachusetts: Allyn \& Bacon.

25.Glass, A. J. \& Saggi, K. (2002). Multinational Firms \& Technology Transfer: Scandinavian Journal of Economics, 104(4), 495-513.

26.Golden, L. (2012). The Effects of Working Time on Productivity and Firms performance. A Reseach Synthesis Paper. Geneva.

27.Harrington, J. M. \& Cooper, C. L. (1997). Health \& Safety Problems Associated with Long Working Hours: A Reviewof the Current Position, 54(6). BJM Career. doi.org/10.1136/oem.54-6.367.

28.Herzberg, F. (2003). One more time: how do you motivate employee?, Harvard Business Review, 81, 56-96.

29.Holkos \& Bousinekis, (2010). Cited in Ranathunga, T. K. (2014). Impact of Job Stress on Work Performance of Consumer Service Employees in Four Hotels. A Jounal of Human Resource, 2(2).

30.IFRS (2012). IAS 19 Employee Benefits: Technical Summary. Retrieved on 29-05-2017 @ 10:25 am.

31.Ivancevich, J. M. (2005). Human resource management, New York. McGraw-Hill/Irwin.

32.Joshi, P. and Venketesh, D. N. (2006). Human Resource Management: Employee Motivation (H. R. Management pg. 325). zenithresearch.org.in/images/stories.

33.Karim, S. \& Roger, M. G. (2005). Job Satisfaction of University academics: Perspective from Uganda Higher Education, 50, 33-56 Doi-10.1007/s10734-004-6346-0.

34.Kawugana, A. (2016). The Impact of Incessant Strikes on the Education Sector in Nigeria, International Journal of Education and Evaluation. ISSN 2489-0073, 2(5), 67-72. www.iiardpub.org.

35.Komal, K. B. \& Tahir, M. Q. (2007). Impact of Employee Participation on Job Satisfaction, Commitment and Employee Productivity. International Review of Business Research Papers, 3(2), 54-68.

36.Mensah, R. (2012). The Impact of Indirect Compensation on Employee Productivity: A Case of Central University College, A Thesis submitted to the Institute of Distance Learning, Kwame Nkrumah University of Science and Technology.

37.Messenger, J. C. (2004). Working Time \& Workers Preferences in Industrialized Countries: Finding the Balance. books.goole.com.

38.Mueller, C. W. \& Kim, S. W. (2008). The Contented Female Worker: Still a Paradox? in Karen A. Hegtvedt, Jody Clay-Warner (ed.). Justice: Advances in Group Processes, 25, 117-149. Emerald Group Publishing Limited.

39.Nadia, K. (2006). Incentive Performance Related Pay and Productivity. Economics Education and Research Consortium, National University Kyiv-Mohyla Academy.

40.Nicholas, B., Aprajit, M., David, M. \& John R. (2010). Ameriacn Economics Review: Paper Proceedings, 100(2), 619-623. Available at: http://www.acaweb.org/articles.php? Doi=101257/aer.100.2619.

41.Nwachukwu, C. C. (2007). Managment Theory and Practice. Onisha, Nigeria: Africana first publishers limited.

42. Onukwube, H. N. (2012). Correlates of job satisfaction amongst quantity surveyors in consulting firms in Lagos, Nigeria. Australasian Journal of Construction Economics and Buildin, 12(2), 43-54. 
43.Presidency, National Salaries, Income and Wages Commission (2007). Circular: Consolidated Tertiary Institutions Salary Structure (CONTISS). www.nsiwc.gov.ng/Docs/policy.

44.Presidency, National Salaries, Income and Wages Commission (2013). Circular: Consolidated Polytechnics and Colleges of Education Academic Staff Salary Structure (CONPCASS) www.informationng.com/teg/consolidated.

45.Rob, B. V. (2015). Structure and Process. Organizational Development. Dresden, Germany. Retrieved from info@structureprocess.com.

46.Roberto, A., Davide A. \& Paolo, P. (2014). Flexible pay systems and labor productivity: Evidence from Emilia-Romagna manufacturing firms. Crescita Italia.

47.Rolloos, M. (1997). Een gezond binnenmilieu betaalt zichzelf terug Praktijkboek Gezonde Gebouwen. October, A2001-3 18.

48.Ross, J. (1981). Information Management. Journal of Information Management, 4(4), 169-176. Doi.org/10.1016/0378-72.

49.Ruch, W. A., \& Hershauer (1974). Factors Affecting Worker Productivity. English Book Illustrated Edition. Temple: Bureau of Business and Economic Research, College of Business Administration. Arizona.

50.Sandilyan, P. R., Mousmumi, M., Amitabh, D. \& Manajit, M. (2012). Effect of Remuneration \& Reward on Employee Motivation. A study of selected Hotels in West Bangal. Zenith International journal of Business Economics \& Management research, 2(4), ISSN 22498826.

51.Scott, S. (2013). Employee Satisfaction Survey Questions: 3 Sample Templates You Use Today. www.qualtrics.com.

52.Song, Y. (2008). Leadership Behaviors and Human Resource Development in Public Sector Organizations Under Conditons of Organizational Uncertainty: Comparative Organizational Study between US and Korea. 3327476. search.proquest.com.

53.Steve, B. (2017). Sample Workplace Survey Questions, Labor Studies Center, 313.577.2191. Wayne state university.s.babson@wayne.edu. Cited on 27/04/2017@12:09.

54.Teboha, M. (2000). Nigerian Education Sector Analysis: An Analytical Synthesis of Performance and Main Issues. New York University.

55.Wegner, E.C. and Snyder, W.M. (2000). Communities of practice: the organizational frontier, Harvard Business Review, January-February, pp. 139-145.

56.Zelenski, J. M., Murphy, S. A., (2008). The Happy Productive Worker Thesis revisited. Journal of Happiness Studies, 9(4), 521-537. DOI: 10.1007/s10902-008-9087-4. Citing Campbell et al (1993). 